\title{
Penentuan Jenis Kelamin Benih Ikan Betutu (Oxyeleotris marmorata Blkr.) dengan Teknik Truss Morphometrics
}

\author{
Atang, Suhestri Suryaningsih dan Muh.Nadjmi Abulias \\ Fakultas Biologi Universitas Jenderal Soedirman \\ E-mail : atangbio98@gmail.com
}

\begin{abstract}
A study on The Gender Determination Of Betutu Germ (Oxyeleotris marmorata Blkr.) by Truss Morphometrics used survey method with Simple Random Sampling design, Betutu's germ as sample were taken from Penjalin reservoir, Brebes. The 26 distance of 13 pile points were based or Truss Morphometrics it were recorded as variables. The result of this research indicated that the size of Betutu's A2 (origin anterior tip of snout at upper jaw - most posterior aspect of neurocranium), A4 (origin posterior point maxillary - origin of pelvic fin), B5 (origin of pelvic fin - origin of dorsal fin), B6 (origin of pelvic fin origin of anal fin), D1 (insertion of anal fin - origin of lower caudal fin) and D3 (insertion of dorsal II fin origin of lower caudal fin) can differentiate the gender of Betutu's germ.
\end{abstract}

Keyword: Betutu, Oxyeleotris marmorata, truss morphometrics, pile points.

\begin{abstract}
Abstrak
Penelitian tentang Penetuan Jenis Kelamin Benih Ikan Betutu (Oxyeleotris marmorata Blkr.) dengan Teknik "Truss Morphometrics" menggunakan metode survey denga teknik pengambilan sampel "Simple Random Sampling". Benih ikan betutu yang dijadikan sampel diambil dari waduk Penjalin Brebes. Variabel yang diamati adalah 26 jarak pengukuran dari 13 titik patokan berdasarkan "Truss Morphometrics". Hasil penelitian ini menunjukkan bahwa ukuran tubuh yang dapat dijadikan sebagai pembeda jenis kelamin benih ikan Betutu yaitu A2 (pangkal moncong atas - ujung dorsal kepala), A4 (pangkal rahang bawah - pangkal sirip perut), B5 (pangkal sirip perut - ujung depan sirip punggung), B6 (pangkal sirip perut - permulaan sirip dubur), D1 (ujung belakang sirip dubur - pangkal sirip ekor bagian bawah) dan D3 (ujung belakang sirip punggung II - pangkal sirip ekor bagian bawah).
\end{abstract}

Kata kunci : Betutu, Oxyeleotris marmorata, truss morphometrics, titik patokan.

\section{Pendahuluan}

Ikan Betutu (Oxyeleotris marmorata) merupakan jenis ikan air tawar liar yang mempunyai nilai ekonomis cukup penting (Komarudin, 2000). Harga ikan Betutu untuk ukuran konsumsi adalah Rp. 125.000,-/kg, sedangkan harga ikan betutu untuk diekspor mencapai Rp. 300.000,-/kg (Kudsiah dan Nur, 2008). Tingginya harga ikan Betutu disebabkan cita rasa yang lezat, daging yang putih dan empuk. Daging ikan Betutu mengandung protein (9-22\%), lemak $(0,1-20$ $\%)$, mineral (1-3\%), vitamin, lecithin, guanine dan sedikit mengandung kolesterol (Arief et al., 2009).

Ciri-ciri morfologis ikan Betutu sebagai berikut : mempunyai bentuk tubuh yang memanjang, berwarna kekuning-kuningan dengan bercak-bercak hitam ke abu-abuan, kepala gepeng, mata besar dan mulut lebar, sirip punggung terdiri dari atas dua bagian terpisah. Sirip punggung pertama lebih rendah daripada sirip punggung kedua.
Warna sirip kecoklat - coklatan sampai coklat keabu-abuan dan terdapat noda-noda hitam yang menyebar di seluruh tubuhnya. Panjang tubuh ikan berkisar antara 10-40 $\mathrm{cm}$ dengan panjang maksimum $50 \mathrm{~cm}$ (Djajadireja, 1977 dalam Gunawan et al., 1999). Ikan betutu tergolong dalam phylum Chordata, kelas Actinopterigii, ordo Perciformes, famili Eleotridae, genus Oxyeleotris dan spesies Oxyeleotris marmorata (Kottelat et al.,1993).

Pemenuhan kebutuhan ikan Betutu selama ini masih mengandalkan dari hasil tangkapan di alam, baik yang masih benih maupun yang siap konsumsi. Apabila hal ini dilakukan secara terus menerus, maka dapat mengakibatkan menurunnya populasi ikan Betutu serta merusak kelestariannya di alam. Salah satu cara untuk mengatasi masalah tersebut adalah dengan melakukan budidaya (Sudrajat dan Effendi, 2002).

Terdapat beberapa macam teknik 
budidaya ikan, salah satu diantaranya dengan cara monoseks. Teknik ini memiliki beberapa keunggulan diantara-nya dapat diketahui jenis kelamin yang tumbuh cepat. Hasil penelitian yang dilakukan pada ikan Gurame (Bhagawati et al., 1998) menunjukkan ikan jantan tumbuh lebih cepat secara signifikan jika dibandingkan dengan ikan betina. Oleh karena itu, budidaya ikan secara monoseks perlu dipertimbangkan sebagai alternatif untuk mengoptimalkan produksi.

Salah satu kendala dalam budidaya monoseks adalah seringkali ditemukan kesulitan dalam penentuan jenis kelamin ikan pada tahap benih, hal ini disebabkan ciri-ciri morfologi yang biasa digunakan untuk membedakan jenis kelamin belum tampak jelas atau belum diketahui, terutama pada ikan-ikan yang dimorfisme seksualnya baru dicapai setelah berukuran relatif besar, termasuk ikan Betutu yang baru dapat diketahui setelah matang kelamin dengan bobot \pm 200 gram panjang $\pm 16,5 \mathrm{~cm}$ (Fatah dan Adjie, 2013).

Perkembangan terakhir, para ilmuwan Canada telah berhasil menemu-kan teknik untuk membedakan atau menentukan jenis kelamin ikan dengan hasil yang cukup meyakinkan yaitu "Truss Morphometrics". Teknik ini berkembang atas dasar bahwa ikan jantan dan betina mempunyai pola pertumbuhan yang berbeda, mengakibatkan perbedaan bentuk tubuh yang faktor penting dalam membedakan jenis kelamin suatu spesies ikan atau antar spesies. Teknik "Truss Morphometrics" merupakan salah satu upaya menggambarkan bentuk ikan dengan cara mengukur bagian-bagian dari tubuh atas dasar titik-titik patokan. Kelebihan teknik ini dibandingkan dengan teknik lainnya adalah lebih konsisten dalam pengukuran, titik-titik patokan yang digunakan dapat mendeteksi suatu gambaran bentuk yang sebenarnya (Nugroho et al., 1991).

Morfometrik adalah bentuk-bentuk luar dari bagian tubuh tertentu yang dijadikan dasar untuk membandingkan, misalnya panjang kepala, lebar interorbital, panjang baku, lebar mata dan lain-lain (Effendie, 1992). Pengukuran ciri morfometrik yang biasa dilakukan secara umum adalah pengukuran seperti panjang total, panjang baku, panjang kepala, tinggi badan. Namun pengukuran terhadap karakter-karakter tersebut dinilai memiliki kelemahan karena hanya memberikan gambaran bentuk tubuh ikan secara umum (Nugroho et al., 1991).

Menunjang kemungkinan budidaya ikan Betutu secara monoseks maka perlu dilakukan upaya penentuan jenis kelamin pada ikan tersebut secara dini. Teknik "Truss Morphometrics" terbukti telah banyak digunakan untuk penentuan jenis kelamin. Oleh karena itu, penggunaan teknik "Truss Morphometrics" diharapkan dapat digunakan untuk membandingkan benih ikan Betutu jantan dan betina dalam upaya menunjang budidaya monoseks.

\section{Materi dan Metode}

Materi yang digunakan yaitu benih ikan Betutu berukuran 10-12 cm dengan bobot 20-35 gram. Metodelogi yang digunakan adalah survey dengan teknik pengambilan sampel "Simple Random Sampling". Ikan Betutu diambil secara acak dari waduk Penjalin Kabupaten Brebes sejumlah 60 ekor.

Berdasarkan Talbott dalam Imron et al. (2000), setiap sampel benih ikan Betutu ditentukan 13 titik yang dijadikan patokan titik "Truss Morphometrics". Titik-titik patokan tersebut adalah : 1) pangkal rahang bawah, 2) pangkal moncong bawah, 3) pangkal moncong atas, 4) batas antara kepala dengan badan/ujung dorsal kepala, 5) permulaan sirip perut, 6) permulaan sirip punggung $I, 7$ ) ujung belakang sirip punggung $I, 8$ ) permulaan sirip dubur, 9) ujung depan sirip punggung II, 10) ujung belakang sirip dubur, 11) ujung belakang sirip punggung II, 12) pangkal sendi ekor bagian bawah, 13) pangkal sendi ekor bagian atas. 


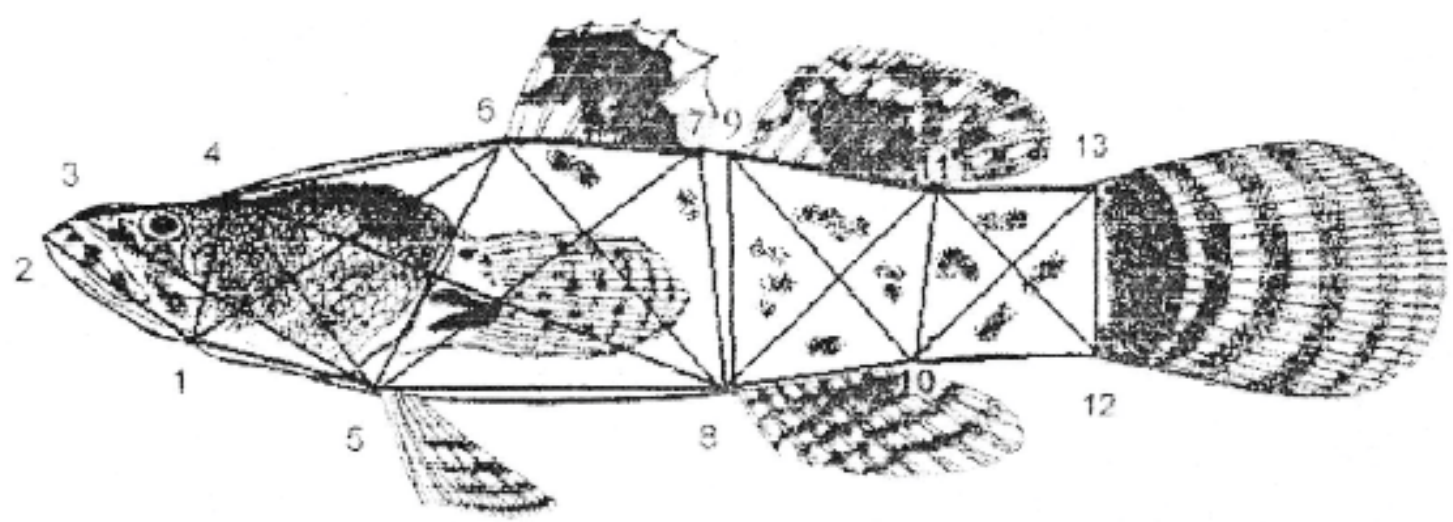

Gambar 1. Posisi titik-titik patokan dalam pengukuran berdasarkan "Truss Morphometrics".

Tabel 1. Keterangan jarak dalam “Truss Morphometrics”.

\begin{tabular}{|c|c|c|}
\hline $\begin{array}{l}\text { Bidang } \\
\text { Truss }\end{array}$ & Kode & Deskripsi Jarak \\
\hline \multirow[t]{5}{*}{ Kepala } & $\mathrm{A} 1(1-2)$ & Pangkal rahang bawah - pangkal moncong bawah \\
\hline & A2 (3-4) & Pangkal moncong atas - ujung dorsal kepala \\
\hline & A3 (1-4) & Pangkal rahang bawah - ujung dorsal kepala \\
\hline & A4 (1-5) & Pangkal rahang bawah - pangkal sirip perut \\
\hline & A5 (3-5) & Pangkal moncong atas - pangkal sirip perut \\
\hline Tubuh & B1 (4-5) & Ujung dorsal kepala-pangkal sirip perut \\
\hline bagian & B2 (4-6) & Ujung dorsal kepala - ujung depan sirip punggung I \\
\hline \multirow[t]{8}{*}{ anterior } & B3 (1-6) & Pangkal rahang bawah - ujung depan sirip punggung I \\
\hline & B4 (4-8) & Ujung dorsal kepala - permulaan sirip dubur \\
\hline & B5 (5-6) & Pangkal sirip perut - ujung depan sirip punggung I \\
\hline & B6 (5-8) & Pangkal sirip perut - permulaan sirip dubur \\
\hline & B7 (5-7) & Pangkal sirip perut - ujung belakang sirip punggung I \\
\hline & B8 (6-7) & Ujung depan sirip punggung I- ujung belakang sirip punggung I \\
\hline & B9 (6-8) & Ujung depan sirip punggung I-permulaan sirip dubur \\
\hline & B10 (7-8) & Ujung belakang sirip punggung I- permulaan sirip dubur \\
\hline Tubuh & C1 (8-9) & Permulaan sirip dubur - ujung depan sirip punggung II \\
\hline bagian & C2 $(8-10)$ & Permulaan sirip dubur - ujung belakang sirip dubur \\
\hline \multirow[t]{4}{*}{ posterior } & C3 (8-11) & Permulaan sirip dubur - ujung belakang sirip punggung II \\
\hline & C4 (9-10) & Ujung depan sirip punggung II - ujung belakang sirip dubur \\
\hline & C5 (9-11) & Ujung depan sirip punggung II - ujung belakang sirip punggung II \\
\hline & C6 (10-11) & Ujung belakang sirip dubur - ujung belakang sirip punggung II \\
\hline \multirow[t]{5}{*}{ Batang ekor } & D1 (10-12) & Ujung belakang sirip dubur - pangkal sendi ekor bag. Bawah \\
\hline & D2 (10-13) & Ujung belakang sirip dubur - pangkal sendi ekor bag. Atas \\
\hline & D3 $(11-12)$ & Ujung belakang sirip punggung II - pangkal sendi ekor bag. Bawah \\
\hline & D4 (11-13) & Ujung belakang sirip punggung II - pangkal sendi ekor bag. Atas \\
\hline & D5 (12-13) & Pangkal sendi ekor bag. Bawah - pangkal sendi ekor bag. Atas \\
\hline
\end{tabular}

Pembuatan histologi gonad benih ikan Betutu dilakukan dengan metode paraffin dan pewarnaan Hematoxilin-Eosin yaitu dengan beberapa tahapan : 1) fiksasi jaringan dengan menggunakan fiksatif Bouin, 2) dehidrasi dengan menggunakan perendaman pada larutan alkohol bertingkat dari $50 \%$ sampai absolut masing-masing selama 2 jam, 3) clearing atau dealkoholisasi dengan menggunakan larutan xylol $2 x$ masing-masing 1 jam, 4) infiltrasi dilakukan dalam oven suhu $58-62{ }^{\circ} \mathrm{C}$ dengan larutan 
xylol:parafin sampai parafin murni masingmasing 1 jam, 5) embedding (penanaman) menggunakan bahan parafin blok dengan titik lebur $\left.58-62{ }^{\circ} \mathrm{C}, 6\right)$ cutting (pengirisan) mengguna-kan alat mikrotom tebal pemotongan $\pm 5 \mu, 7$ ) pewarnaan dengan $\mathrm{HE}$, 8) mounting, 9) pengamatan sampel histologi gonad.

Hasil pengamatan gonad secara histologi digunakan untuk pengelompokan data "Truss Morphometrics", data yang diperoleh hasil pengukuran antara benih ikan Betutu jantan dan betina selanjutnya dianalisis dengan uji t.

\section{Hasil dan Pembahasan}

Hasil penelitian yang telah dilakukan dari 60 ekor benih ikan Betutu, berdasarkan pendekatan histologi melalui pengamatan mikroskopis pada gonadnya diperoleh 33 ekor benih ikan Betutu jantan dan 27 ekor benih ikan Betutu betina.

Penentuan jenis kelamin ikan dilakukan dengan pendekatan histologi melalui pengamatan mikroskopis gonadnya. Gonad betina ditandai dengan adanya rongga ovarium, lamella, sitoplasmasel folikel, oosit, ooplasma, nucleus, nucleo-lus, mempunyai substansi telur yang terdiri dari butir-butir telur, gelembung kuning telur dan tetes lemak. Gonad jantan ditandai adanya dinding rongga (lumina), sitoplasma, tubula seminiferus, sel sertoli, sel leydig, nucleus, nucleolus dan spermatosit (Sa'adah, 1996).

Pada benih ikan Betutu secara histologi testis dan ovariumnya dapat dibedakan dengan jelas. Testis hanya tampak berupa titik-titik kecil dengan jumlah banyak dan rapat, sedangkan ovarium tampak berbentuk bulatan besar (ukuran lebih besar dibandingkan testis) dan bagian inti berwarna lebih pucat dan cerah terletak di tengah. Hal ini sesuai dengan pernyataan Zairin (2002), bahwa bakal testis pada ikan memiliki ukuran lebih kecil dibandingkan dengan bakal ovarium, bakal sel sperma hanya tampak berupa titik-titik kecil berjumlah banyak, selnya hanya sedikit mengandung sito- plasma, sedangkan bakal sel telur tampak berbentuk bulatan besar dan bagian intinya berada di tengah dengan warna lebih pucat dikelilingi sitoplasma yang lebih banyak dibandingkan dengan sel testis, warna lebih cerah.

Berdasarkan hasil pengukuran tubuh benih ikan Betutu dengan teknik "Truss Morphometrics" didapat adanya perbe-daan bentuk morfologi antara benih ikan jantan dan benih ikan betina. Nilai rata-rata pengukuran titik "Truss Morpho-metrics" antara benih ikan jantan dan benih ikan betina dapat dilihat pada tabel 2.

Tabel 2. Rata-rata ukuran benih ikan Betutu (Oxyeleotris marmorata Blkr.)

\begin{tabular}{|c|c|c|c|c|c|c|c|}
\hline \multirow[t]{2}{*}{$\begin{array}{l}\text { Jarak } \\
\text { "Truss" }\end{array}$} & \multicolumn{2}{|c|}{ Rata-rata } & \multirow[t]{2}{*}{$\begin{array}{l}\text { Kaidah } \\
\text { Keputusan }\end{array}$} & \multirow[t]{2}{*}{$\begin{array}{l}\text { Jarak } \\
\text { "Truss" }\end{array}$} & \multicolumn{2}{|c|}{ Rata-rata } & \multirow[t]{2}{*}{$\begin{array}{c}\text { Kaidah } \\
\text { Keputusan }\end{array}$} \\
\hline & Jantan & Betina & & & Jantan & Betina & \\
\hline A1 & 2,18 & 2,19 & tn & B10 & 2,23 & 2,28 & tn \\
\hline A2 & 1,64 & 1,81 & sn & C1 & 2,25 & 2,26 & tn \\
\hline A3 & 1,58 & 1,64 & tn & $\mathrm{C} 2$ & 1,44 & 1,46 & tn \\
\hline A4 & 1,57 & 1,72 & sn & C3 & 2,30 & 2,34 & tn \\
\hline A5 & 3,51 & 3,56 & tn & C4 & 2,53 & 2,55 & tn \\
\hline B1 & 2,43 & 2,44 & tn & C5 & 1,84 & 1,86 & tn \\
\hline B2 & 2,75 & 2,65 & tn & C6 & 1,57 & 1,58 & tn \\
\hline B3 & 3,18 & 3,29 & tn & D1 & 2,79 & 2,90 & $\mathrm{n}$ \\
\hline B4 & 5,30 & 5,34 & tn & D2 & 3,01 & 3,06 & tn \\
\hline B5 & 2,44 & 2,58 & sn & D3 & 3,12 & 3,21 & $\mathrm{n}$ \\
\hline B6 & 3,25 & 3,43 & sn & D4 & 2,61 & 2,62 & tn \\
\hline B7 & 3,31 & 3,32 & tn & D5 & 1,61 & 1,61 & tn \\
\hline B8 & 1,44 & 1,44 & tn & PB & 10,99 & 11,06 & tn \\
\hline B9 & 3,18 & 3,18 & tn & Bobot & 28,21 & 30,58 & $\mathrm{n}$ \\
\hline
\end{tabular}

Keterangan:

tn : tidak nyata

$\mathrm{n}$ : nyata

sn : sangat nyata 
Rata-rata pengukuran terhadap 26 titik "Truss Morphometrics" terlihat bahwa nilai rata benih ikan Betutu betina lebih besar dibanding dengan benih ikan jantan. Hasil uji $\mathrm{t}$ menunjukkan berbeda sangat nyata, perbedaan tersebut terletak pada jarak $\mathrm{A} 2$ (pangkal moncong atas - ujung dorsal kepala), A4 (pangkal rahang bawah pangkal sirip perut), B5 (pangkal sirip perut ujung depan sirip punggung I), B6 (pangkal sirip perut - permulaan sirip dubur). Sedangkan yang berbeda nyata terletak pada jarak D1 (ujung belakang sirip dubur pangkal sirip ekor bagian bawah) dan D3 (ujung belakang sirip punggung II - pangkal sirip ekor bagian bawah). Menurut Nurokhmi (2002), jarak yang menghu-bungkan garis vertikal pada bagian tubuh ikan diduga sebagai karakter pertumbuh-an vertikal sedangkan jarak yang menghubungkan garis secara horisontal pada bagian tubuh diduga sebagai karakter pertumbuhan horisontal.

Bobot rata-rata benih ikan Betutu menunjukkan bahwa bobot benih ikan betina lebih besar dibandingkan benih ikan jantan, hasil uji menunjukkan perbedaan yang nyata. Benih ikan betina lebih banyak menggunakan pakan yang diperolehnya untuk pertumbuhan tubuh, sedangkan pada ikan jantan pakan yang diperolehnya lebih banyak digunakan untuk perkembangan gonadnya daripada untuk pertumbuhan tubuh, sehingga kematangan gonad pada ikan jantan relatif lebih cepat (Sa'adah, 1996).

Perbedaan jarak truss pada benih ikan Betutu jantan dan betina dikarenakan sifat genotif dari ikan jantan dan betina berbeda, umumnya karakter morfologi menggambarkan sebagian besar dari sifat genotif (Mayr dan Ashlock dalam Nurokhmi, 2002).

Sebagai pembanding, penelitian Suryaningsih et al. (1999), pada berbagai ukuran tubuh ikan Gurami dapat digunakan untuk membedakan ikan jantan dan betina. Hasil yang diperoleh relatif sama dengan hasil penelitian pada benih ikan Betutu, yaitu ukuran yang membedakan terletak pada jarak antara pangkal sirip anal sampai pelipatan pangkal ekor bagian bawah.

\section{Simpulan}

Terdapat beberapa perbedaan pola "Truss Morphometrics" pada behih ikan Betutu jantan dan betina. Ukuran tubuh yang dapat dijadikan sebagai pembeda jenis kelamin benih ikan Betutu yaitu jarak antara pangkal moncong atas dan ujung dorsal kepala, jarak antara pangkal pangkal rahang bawah dan pangkal sirip perut, jarak antara pangkal sirip perut dan ujung depan sirip punggung I, jarak antara pangkal sirip perut dan permulaan sirip dubur, jarak antara ujung belakang sirip dubur dan pangkal sirip ekor bagian bawah serta jarak antara ujung belakang sirip punggung II dan pangkal sirip ekor bagian bawah. Secara morfologi pada beih ikan Betutu jantan bagian kepala lebih pendek dan pipih, bagian perut lebih pendek, daerah ekor lebih sempit dan pendek apabila dibandingkan dengan benih ikan Betutu betina.

\section{Daftar Pustaka}

Arief, M., I. Triasih dan W. P.Lokapirnasih. 2009. Pengaruh Pemberian Pakan Alami dan Pakan Buatan terhadap Pertumbuhan Benih Ikan Betutu (Oxyeleotris marmorata Bleeker.). Jurnal IImiah Perikanan dan Kelangsungan Volum 1.

Bhagawati, D., Suryaningsih, S., Rukayah, S., dan Marhaendro, S. 1998. Upaya peningkatan Produksi Ikan Gurame dengan Teknik Pemeliharaan Tunggal Kelamin dan dengan pakan Tambahan Tepung Daun Singkong. Laporan Hasil Penelitian Fakultas Biologi, Universitas Jenderal Soedirman, Purwokerto.

Effendie, M.I. 1992. Metoda biologi perikanan. Fakultas Perikanan. Bagian Ichtiology IPB.

Fatah, K dan S. Adjie,. 2013. Biologi Reproduksi Ikan Betutu (Oxyeleotris marmorata) di Waduk Kedung Ombo Propinsi Jawa Tengah. Jurnal BAWAL Vol. 5 (2) Agustus 2013 : 89-96.

Gunawan., S. Diana., S. Astuty \& Iskandar. 1999. Studi biologi ikan betutu ((Oxyeleotris marmorata) di perairan Waduk Cirata. Tesis Lembaga Penelitian Universitas Padjadjaran. (Tidak dipublikasikan).

Imron, Z.A. Otong dan Subagyo. 2000. Keragaman Truss Morphometrics pada Ikan Mas (Cyprinus carpio) galur Majalaya, Rajadanu, Wildan dan Sutina. Pusat Penelitian dan Pengembangan Eksplorasi Laut dan Perikanan. Jakarta. 
Komarudin, A.K.U. 2000. Betutu : Pemijahan Secara Alami dan Induksi, Pembesaran di Kolam dan Hampang. Penebar Swadaya, Jakarta.

Kottelat, M., A.J. Whitten., Kartikasari S.N. \& S. Wirjoatmodjo. 1993. Ikan Air Tawar Indonesia Bagian Barat dan Sulawesi. Periplus Editions Limited. Jakarta.

Kudsiah, H. dan A. Nur. 2008. Efisiensi Usaha Pembesaran Ikan Betutu Dengan Pemberian Berbagai Bentuk Pakan dari Ikan Sepat Rawa dan Udang Rucah. Jurnal Sains dan Teknologi Volum 8.

Nugroho, E.N.A. Wahyudi dan Sudarto. 1991. Penentuan Jenis kelamin Ikan Mas dengan Membandingkan Bentuk Tubuh Melalui Teknik "Truss Morphometrics". Buletin Penelitian Perikanan Tawar. Vol 10 No. 1. Balitkanwar.

Nurokhmi. 2002. Variasi Ikan Nilem Seruni, Mangut dan Gunung (Osteochilus hasselti C.V) berdasarkan Teknik "Truss Morphometrics". Skripsi. Fakultas Biologi Universitas Jenderal Soedirman, Purwokerto. (Tidak dipublikasikan).
Sa'adah, L. 1996. Penentuan Jenis Kelamin Ikan Nilem (Osteochilus hasselti C.V) pada Umur Tiga Bulan dengan Teknik "Truss Morphometrics". Skripsi. Fakultas Biologi Universitas Jenderal Soedirman, Purwokerto. (Tidak dipublikasikan).

Sudrajat, A.O dan I. Effendi. 2002. Pemberian Pakan Buatan Bagi Benih Ikan Betutu, Oxyeleotris marmorata (BLKR.). Jurnal Akuakultur Indonesia, Volum 1.

Suryaningsih, S., Bhagawati, D \& Nuryanto, A. 1999. Evaluasi Jenis Kelamin Ikan Gurame (Osphrenomus gourami Lac) Pada Berbagai Ukuran. Laporan Penelitian, Fakultas Biologi, Universitas Jenderal Soedirman. (Tidak dipublikasikan).

Zairin, M. Jr. 2002. Sex Reversal: Memproduksi Benih Ikan Jantan atau Betina. Penebar Swadaya, Jakarta. 